\title{
PENERAPAN MODEL TRI PRAMANA SPA DITINJAU DARI MOTIVASI SISWA TERHADAP KETERAMPILAN BERPIKIR KRITIS SISWA
}

\author{
Ida Bagus Ari Arjaya, Kadek Rahayu Puspadewi \\ Program Studi Pendidikan Biologi FKIP Unmas Denpasar \\ email:ariarjayaunmas@gmail.com
}

\begin{abstract}
ABSTRAK
Tujuan dari penelitian ini adalah, 1) Untuk menganalisis perbedaan kemampuan berpikir kritis antara Model Tri Pramana SPA (MTPSPA) dengan Model Pembelajaran Konvensional (MPK), 2)Untuk menganalisis perbedaan kemampuan berpikir kritis antara MTPSPA dengan MPK pada siswa dengan motivasi belajar tinggi, 3) Untuk menganalisis perbedaan kemampuan berpikir kritis antara MTPSPA dengan MTPSPA pada siswa dengan motivasi belajar rendah, 4) Untuk menganalisis pengaruh interaktif antara model pembelajaran dan motivasi belajar terhadap kemampuan berpikir kritis siswa.

Populasi penelitian ini adalah seluruh peserta didik SMP Negeri 7 Denpasar tahun ajaran 2016/2017. Penentuan sampel yang akan digunakan dalam penelitian ini menggunakan metode group random sampling dengan rancangan quasi experiment.Uji prasyarat dalam penelitian ini menggunakan yaitu uji validitas internal penelitian dan interrater reliability. Penelitian ini menggunakan teknik analisis Analyze of Variant (ANAVA) dua jalur menggunakan bantuan software SPSS 17 for Windows.Adapun hasil yang diperoleh dalam penelitian ini adalah yaitu 1) terdapat perbedaan kemampuan berpikir kritis yang signifikan antara MTPSPA dengan MPK $(\mathrm{p}=0,000<\alpha=0,05), 2)$ terdapat perbedaan kemampuan berpikir kritis yang signifikan antara MTPSPA dengan MPK pada siswa yang motivasi belajarnya tinggi $(\mathrm{p}=0,000<\alpha=0,05), 3)$ terdapat perbedaan kemampuan berpikir kritis yang signifikan antara MTPSPA dengan MPK pada siswa yang motivasi belajarnya rendah $(\mathrm{p}=0,000<\alpha=0,05), 4)$ tidak terdapat pengaruh interaksi antara model pembelajaran dengan motivasi belajar siswa terhadap kemampuan berpikir kritis siswa $(\mathrm{p}=0,482>\alpha=0,05)$.
\end{abstract}

Kata Kunci: Kemampuan Berpikir Kritis, Model Tri Pramana, Motivasi Belajar

\section{ABSTRACT}

The purposes of this research are to analyze: 1) The difference of critical thinking ability between Model Tri Pramana SPA (MTPSPA) and Model Pembelajaran Konvensional (MPK), 2) the differences in critical thinking skills between MTPSPA and MPK in students with high learning motivation, 3) The differences in critical thinking skills between MTPSPA and MTPSPA in students with low learning motivation, 4) The interactive effect between learning model and learning motivation toward students' critical thinking ability.

The population of this study was all students of SMP Negeri 7 Denpasar academic year 2016/2017. The Samping technique that was used was group random sampling method with a quasi experiment design. The prerequisite data analysis consisted of internal validity analysis and interrater reliability. Two Way Analyze of Variant (ANAVA) by using SPSS 17 for Windows Software was used as the data analysis technique. The result of the present study are 1) there was significant difference of students' critical thinking between MTPSPA and MPK $(p=0,000<\alpha=$ $0,05), 2)$ there was significant difference of students' critical thinking between MTPSPA and MPK for high motivation ( $p=0,000<\alpha=0,05)$, 3) there was significant difference of students' critical thinking between MTPSPA and MPK for low motivation $(p=0,000<\alpha=0,05), 4)$ there is no interaction effect between learning model and students' learning motivation toward students' critical thinking $(p=0,482>\alpha=0,05)$.

Keywords: Critical Thinking, Model Tri Pramana SPA, Learning Motivation 


\section{PENDAHULUAN}

Globalisasi, kebutuhan ekonomi, dan keterlibatan masyarakat yang rendah di dalam mendukung program pemerintah merupakan urgensi bagi siswa untuk segera mengembangkan skills dan pengetahuan untuk mengatasi permasalahan tersebut. Akselerasi informasi data tidak dapat dibendung lagi melalui sistem digitalisasi yang terkoneksi dengan piranti internet. dengan demikian, penguasaan IPTEKS yang disertai dengan sumber daya manusia (human capital) yang baik dan dilandasi oleh karakter kepribadian bangsa (character building) akan mampu mendorong perbaikan mutu pendidikan di Indonesia.

Pemerataan pendidikan yang berkualitas yang masih menjadi masalah utama bagi pendidikan di Indonesia. Lebih lanjut data Third in International Mathematics Science and Study (TIMSS) tahun 2011, peringkat siswa Indonesia bertengger di posisi 38 dari 42 negara untuk prestasi matematika, dan menduduki posisi 40 dari 42 negara untuk prestasi sains. Rata-rata skor prestasi matematika dan sains berturut-turut adalah 386 dan 406, masih berada signifikan di bawah skor rata-rata internasional (Sadewo, 2015). Kondisi yang tidak jauh berbeda juga ditunjukan dari hasil studi yang dilakukan Programme for International Student Assesment(PISA). Hasil studi PISA 2012, Indonesia berada di peringkat ke-64 dari 65 negara peserta dengan skor rata-rata 375 , sedangkan skor rata-rata internasional 500 (OECD,2013). Hal tersebut mengindikasikan bahwa kemampuan siswa Indonesia masih sangat rendah di bidang matematika dan sains dan jauh dari standar pendidikan global. Keterampilan berpikir merupakan salah satu problem krusial dari uraian faktafakta yang telah dijelaskan sebelumnya.

Kemampuan berpikir tingkat tinggi sangat penting untuk memecahkan masalah-masalah kontekstual yang terkait dengan kehidupan sehari-hari dan bersifat ill structured problem. Kemampuan berpikir tingkat tinggiterdiri atas empat kelompok yaitu berpikir kritis, pemecahan masalah, pembuatan keputusan, dan berpikir kreatif (Liliasari, 2000; Johnson, 2002). Critical thinking (berpikir kritis) merupakan salah satu skills utama yang harus dimiliki oleh setiap siswa di dalam menghadapi kompetisi dunia kerja pada abad 21. Pada umumnya proses pengajaran di kelas-kelas sains khususnya biologi mengunakan pendekatan deduksi teori tanpa diimbangi oleh verifikasi dari pendekatan induktif. Tentu saja hal ini akan menghambat dan mengurangi kepekaan siswa untuk mengadapi berbagai jenis masalah yang kompleks dan memerlukan lebih dari satu jenis cara penyelesaian.

Siklus belajar merupakan salah satu model pembelajaran yang berlandaskan paham konstruktivistik dan memiliki fleksibilitas yang sangat tinggi untuk diterapkan pada berbagai karakteristik siswa. Dalam skala yang lebih sempit yaitu terkait dengan kearifan lokal (local wisdom) masyarakat Bali, model siklus belajar dikembangkan lebih lanjut menjadi model siklus belajar Tri Pramana. Tri Pramana terdiri dari pratyaksa paramana, anumana pramana dan agama pramana. Tri pramana juga merupakan tiga kemampuan dasar yang dimiliki manusia, meliputi bayu, sabda, dan idep (Subagia dan Wiratma, 2006). Dalam konteks belajar, ketiga potensi pratyaksa pramana, anumana pramana dan agama atau sabda pramana akan 
mendukung satu sama lain. Pratyaksa pramana adalah cara belajar yang dilakukan dengan pengamatan langsung terhadap materi pelajaran. Sabda pramana adalah cara belajar yang dilakukan dengan memperoleh informasi langsung dari sumber belajar yang dapat dipercaya, sedangkan anumana pramana adalah cara belajar yang dilakukan dengan penalaran terhadap materi yang tidak bisa dijangkau secara langsung. Pada hakikatnya, seluruh proses pencarian ilmu pengetahuan dapat dilaksanakan dengan tiga proses yang dikenal dengan Tri Pramana.

Berbeda halnya dengan model pembelajaran konvensional yang bersifat parsial dan seringkali tumpang tindih pada setiap tahapan, model siklus belajar Tri Pramana memiliki sinergisme didalam mengembangkan proses mental siswa (minds on) dan keterampilan siswa (hands on). Dua nilai penting dari model Tri Pramana di dalam proses pembelajaran adalah kemampuannya di dalam mengakomodasi berbagai aspek pembelajaran meliputi keterampilan proses, hasil belajar, sikap terhadap sains, serta proses mental seperti berpikir kritis dan mengakomodasi pemanfaatan model pembelajaran yang berlandaskan kearifan lokal masyarakat Bali.

$$
\text { Umumnya guru-guru sains }
$$
khususnya pada bidang studi biologi kesulitan di dalam mengembangkan ketrampilan berpikir kritis siswa secara simultan dengan aspek belajar yang lain. Namun, model Tri Pramana SPA merupakan model siklus belajar yang didesain khusus untuk mengembangkan kemampuan berpikir kritis siswa pada jenjang SMP (Sekolah Menengah Pertama). Model SPA dimulai dari penggunaan informasi yang diberikan oleh guru atau buku teks sebagai sumber belajar untuk mengawali pelajaran (sabda). Pengetahuan yang diperoleh dari informasi yang diberikan guru atau yang diperoleh dari buku-buku teks digunakan sebagai panduan untuk melakukan pengamatan langsung (pratyaksa). Aktivitas metakognisi dari sumber-sumber pengetahuan yang dilakukan secara berkelompok pada fase ini. Pengetahuan yang diperoleh dari kegiatan pertama dan kedua digunakan untuk membangun pemahaman terhadap objek-objek pelajaran lainnya yang sejenis yang tidak dapat diamati secara langsung (anumana). Pada fase pratyaksa dan anumana, merupakan fase reinforcement dimana siswa diajak untuk melakukan pengamatan terhadap sesuatu selanjutnya mengembangkan pengetahuan dengan jalan melakukan brainstorming.

SMP 7 Denpasar merupakan salah satu SMP unggulan di kota Denpasar dengan prestasi akademik yang baik dengan tingkat kelulusan UN mencapai $100 \%$ pada tahun 2015. Namun, masih terdapat kendala mengenai pengembangan kemampuan berpikir kritis siswa. Berdasarkan hasil observasi awal, yaitu wawancara dengan guru-guru bidang studi Biologi diketahui bahwa siswa masih mengalami kesulitan di dalam memecahkan permasalahan-permasalahan kompleks yang yang bersifat divergen dan menuntut keterampilan berpikir kritis.

Terdapat faktor lain yang juga mendukung kemampuan berpikir kritis siswa yaitu, gaya belajar, sikap ilmiah, dan motivasi belajar siswa. Faktor terakhir merupakan faktor yang umumnya lebih mudah divariasikan dengan menggunakan berbagai jenis model pembelajaran. Motivasi belajar mengandung makna dorongan internal dan eksternal yang memberi semangat, arah, dan kegigihan 
perilakuyang penuh 183 itera, terarah, dan bertahan lama di dalam proses pembelajaran (Santrock,2008; Glynn \& Koballa, 2006). Dengan memperhatikan aspek motivasi belajar dalam implementasi Model Tri Pramana SPA maka guru akan mampu mengembangkan keterampilan berpikir kritis siswa secara maksimal. Berdasarkan uraian tersebut penting untuk dikaji bagaimana "Pengaruh Model Tri Pramana SPA ditinjau dari motivasi belajar terhadap kemampuan berpikir kritis siswa kelas VII SMP N 7 Denpasar". Dengan demikian tujuan dari penelitian ini dapat dirumuskan sebagai berikut: 1) Untuk menganalisis perbedaan kemampuan berpikir kritis antara Model Tri Pramana SPA (MTPSPA) dengan Model Pembelajaran Konvensional (MPK), 2)Untuk menganalisis perbedaan kemampuan berpikir kritis antara MTPSPA dengan MPK pada siswa dengan motivasi belajar tinggi, 3) Untuk menganalisis perbedaan kemampuan berpikir kritis antara MTPSPA dengan MTPSPA pada siswa dengan motivasi belajar rendah, 4) Untuk menganalisis pengaruh interaktif antara model pembelajaran dan motivasi belajar terhadap kemampuan berpikir kritis siswa.

\section{METODOLOGI}

Populasi target penelitian ini adalah seluruh peserta didik SMP Negeri 7 Denpasar, sedangkan populasi terjangkau adalah semua siswa kelas VII SMP Negeri 7 Denpasar tahun ajaran 2016/2017. Penentuan sampel yang akan digunakan dalam penelitian ini menggunakan metode group random sampling dengan rancangan quasi experiment. Variabel bebas (independent) dalam penelitian adalah model pembelajaran (Model Pembelajaran
Konvensional dan Model Tri Pramana SPA), sedangkan terikat dalam penelitian ini adalah kemampuan berpikir kritis siswa. Lebih lanjut terdapat variabel moderator yaitu motivasi belajar yang mengelompokkan Model Pembelajaran Konvensional dan Model Pembelajaran Tri Pramana SPA menjadi dua bagian yaitu yang memiliki motivasi tinggi dan motivasi rendah.

Sebelum dilaksanakan analisis data penelitian maka terlebih dahulu dilaksanakan uji prasyarat penelitian dengan menggunakan prasyarat penelitian yaitu uji validitas internal penelitian dan interrater reliability. Selanjutnya untuk uji homogenitas data penelitian digunakan uji Levene Homogenity of Statistic dan normalitas data dengan menggunakan formula Kolmogorov Smirnov. Teknik analisis data yang digunakan dalam penelitian ini adalah Analyze of Variant (ANAVA) dua jalur menggunakan bantuan software SPSS 17 for Windows.

\section{PEMBAHASAN}

\section{Hasil}

\section{Hasil Analisis Deskriptif Penelitian}

Hasil statistik deskriptif penelitian merupakan gambaran awal untuk menjelaskan sebaran data penelitian.Tabel 5.1 berikut menguraikan statistik deskriptif kemampuan berpikir kritis siswa dari masing Model Tri Pramana SPA untuk kelas eksperimen. 
Tabel 5.1 Statistik Deskriptif Kemampuan Berpikir Kritis Model Tri Pramana SPA

\begin{tabular}{llrr}
\hline & Descriptives & & \\
\hline KelasEksperimen & Mean & Statistic & Std. Error \\
\cline { 2 - 4 } & Median & 24.3750 & 1.04786 \\
& Variance & 26.5625 & \\
& Std. Deviation & 43.920 & \\
& Minimum & 6.62724 & \\
& Maximum & 9.38 & \\
& Range & 34.38 & \\
& & 25.00 & \\
\hline
\end{tabular}

Berdasarkan Tabel 5.1, maka dapat Sehingga dapat disimpulkan bahwa nilai diketahui bahwa rata-rata nilai mean tersebut dapat dipergunakan sebagai kemampuan berpikir kritis siswa adalah representasi dari seluruh data $\bar{X}=24,37$. Sedangkan nilai dari standar keterampilan berpikir kritis siswa kelas deviasi data adalah 6,62. Hal ini berarti eksperimen di SMP Negeri 7 Denpasar. bahwa penyimpangan dari mean masih Selanjutnya nilai statistik deskriptif dari berada dalam batas toleransi, karena nilai kelas kontrol dapat ditampilkan pada standar deviasi tersebut berada jauh Tabel 5.2.

dibandingkan nilai mean.

Tabel 5.2. Statistik Deskriptif Kemampuan Berpikir Kritis Model Konvensional

\begin{tabular}{llrr}
\hline & Descriptives & & \\
\hline Kelaskontrol & Mean & Statistic & Std. Error \\
& Variance & 12.3047 & .99639 \\
& Std. Deviation & 39.712 & \\
& Minimum & 6.30174 & \\
& Maximum & 3.13 & \\
& Range & 29.69 & \\
& & 26.56 & \\
\hline
\end{tabular}

Tabel 5.2 memperlihatkan bahwa nilai mean kemampuan berpikir kritis dari kelas kontrol yaitu $\bar{X}=12,30$. Sedangkan nilai dari standar deviasi data adalah 6,3 . Hal ini mengandung makna bahwa penyimpangan dari mean masih berada dalam batas toleransi, karena nilai standar deviasi tersebut berada jauh dibandingkan nilai mean. Sehingga data penelitian diatas dapat diasumsikan bersifat representative di dalam mengukur kemampuan berpikir kritis siswa kelas kontrol di SMP Negeri 7 Denpasar.
Perbandingan kedua mean yaitu antara kelas eksperimen dengan kelas kontrol memperlihatkan perbedaan yang cukup signifikan. Dimana nilai mean kelas eksperimen ( $\bar{X}=24,37)$ lebih besar jika dibandingkan dengan nilai mean kelas kontrol $(\bar{X}=12,30$.). Secara deskriptif dapat disimpulkan bahwa kemampuan berpikir kritis pada siswa kelas eksperimen lebih baik jika dibandingkan dengan kelas kontrol.

\section{Uji Validitas Penelitian}


Dalam penelitian ini digunakan uji validitas internal yaitu dengan menggunakan dua orang expert judgement pendidikan yang akan menilai content validity, face validity, dan construct validity kemampuan berpikir kritis dan motivasi belajar siswa. Expert judgementyang pertama yaitu Gusti Ayu Dewi Setiawati, S.Pd,,M.Pd. dan expert judgement yang kedua yaitu $\mathrm{Ni}$ Wayan
Ekayanti, S.Pd.,M.Pd. Secara umum masukan dari kedua expert judgement adalah mengenai konteks bahasa yang harus disesuaikan dengan tingkat perkembangan siswa yaitu dalam hal ini adalah siswa SMP. Selanjutnya hasil analisis dengan menggunakan formula Gregory dapat ditampilkan pada Tabel 5.3 .

Tabel 5.3 Tabulasi Silang Analisis Kemampuan Berpikir Kritis Siswa.

\begin{tabular}{llll} 
& & \multicolumn{2}{c}{ Penilai I } \\
\cline { 3 - 4 } \multicolumn{1}{c}{ Penilai II } & Kurang Relevan & $\mathrm{A}=0$ & Sangat Relevan \\
& Sangat Relevan & $\mathrm{C}=0$ & $\mathrm{~B}=0$ \\
Keterangan: & & $\mathrm{D}=24$ \\
Penilai I & $=$ Gusti Ayu Dewi Setiawati, & S.Pd.,M.Pd. \\
Penilai II & $=$ Ni Wayan Ekayanti,S.Pd.,M.Pd. \\
Validitas isi instrumen critical thinking & $=\frac{D}{A+B+C+D}$ \\
& $=\frac{24}{0+0+0+24}$ \\
& $=1$
\end{tabular}

\section{Uji Reliabilitas Data Penelitian}

Reliabilitas atau keajegan merupakan salah faktor yang berpengaruh terhadap hasil implementasi instrument penelitian. Adapun uji reliabilitas dalam penelitian ini yaitu dengan menggunakan inter rater reliability. Yaitu analisis reliabilitas instrument berdasarkan korelasi rating yang diberikan antara peneliti dengan numerator (expert judgment). Analisis instrument kemampuan berpikir kritis siswa menggunakan teknik cross-tabulation dengan korelasi Kappa. Adapun hasil analisis reliabilitas dapat ditampilkan sebagai berikut. 
Tabel 5.4 Hasil Analisis Inter-Reliability Instrumen Kemampuan Berpikir Kritis Siswa Symmetric Measures

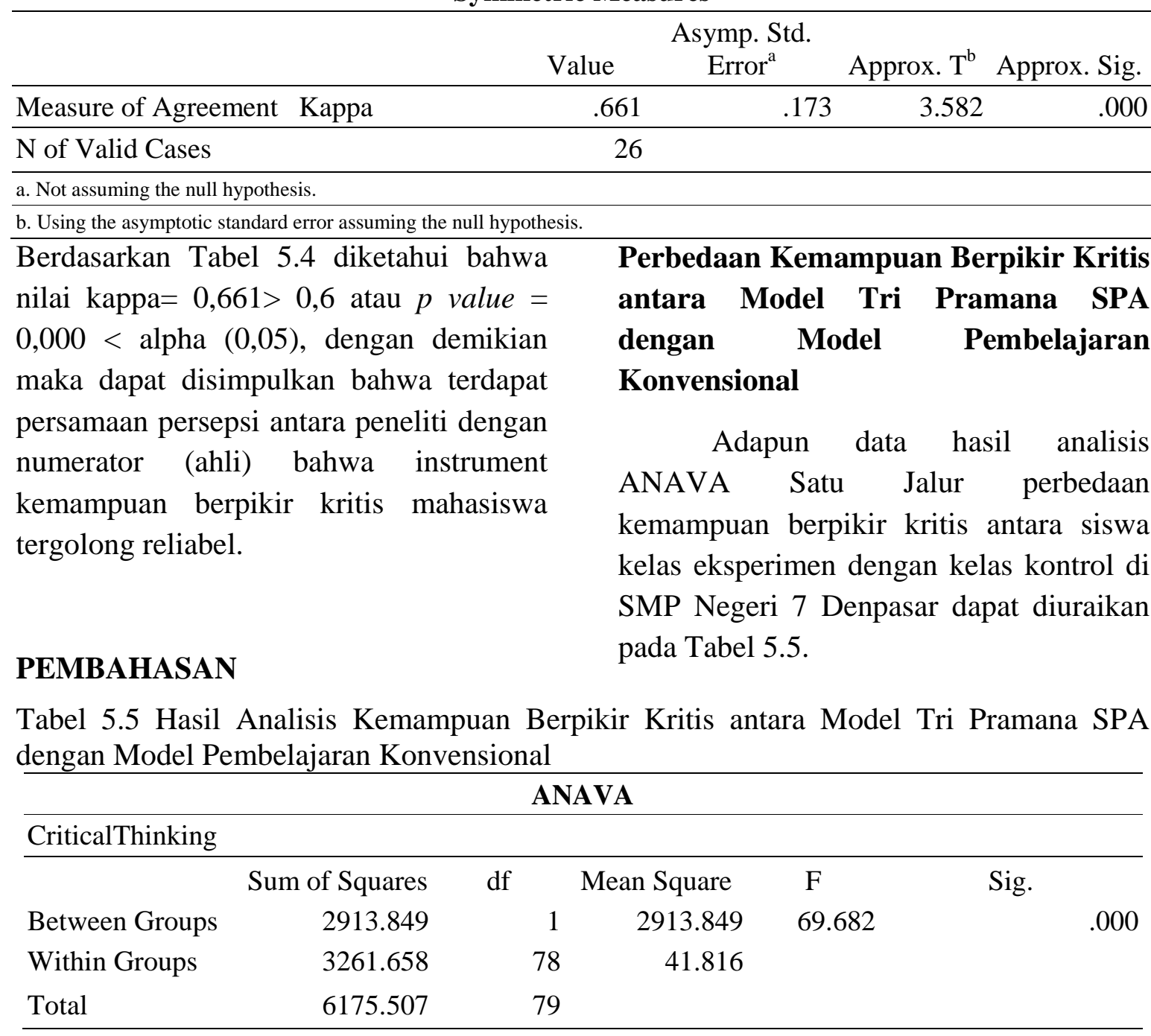

Hasil analisis Tabel 5.5 menunjukkan bahwa nilai $\mathrm{p}=0,000<\alpha=0,05$, sehingga maka Ho ditolak dan $\mathrm{H} 1$ diterima. Dengan demikian dapat disimpulkan bahwa terdapat perbedaan yang signifikan antara Model Tri Pramana SPA dengan Model Konvensional. Hal ini sesuai dengan perbandingan nilai mean kedua buah model yang menunjukkan bahwa Model Tri Pramana $\operatorname{SPA}(\bar{X}=24,37)$ lebih baik jika dibandingkan dengan Model Pembelajaran Konvensional $(\bar{X}=12,30)$.

Model Tri Pramana SPA menekankan siswa pada kegiatan-kegiatan autentik di dalam proses mengolah data dari sumber sumber belajar siswa. Pada
Fase Sabda Pramana sebelumnya guru telah menugaskan siswa untuk mencari sumber belajar yang autentik mengenai proses penyaringan darah di ginjal. Kompilasi berbagai jenis materi bacaan yang siswa bawa ke sekolah menyebabkan siswa harus selektif di dalam mengidentifikasi materi materi yang valid dan dapat dipercaya. Siswa akan mengeluarkan argumentasi dan evaluasinya mengenai materi yang mereka peroleh. Berdiskusi mengenai materi dan pengembangannya akan meningkatkan kemampuan berpikir kritis siswa. Siswa akan belajar untuk mendengar dan memahami pendapat temannya dalam satu 
kelompok. Dan memberikan argumentasi mengenai hal-hal yang mereka anggap benar. Peranan guru dalam fase ini sangat penting untuk memfasilitasi siswa apabila sulit untuk ditemui kata sepakat dalam identifikasi materi mereka. Selain itu Pemahaman deduksi siswa akan meningkat sejalan dengan proses identifikasi dan elaborasi Model Tri Pramana SPA.

\section{Perbedaan Kemampuan Berpikir Kritis antara Model Tri Pramana SPA dengan Model Pembelajaran Konvensional pada Siswa Dengan Motivasi Belajar Tinggi}

Hasil tabulasi ANAVA satu jalur perbedaan kemampuan berpikir kritis siswa antara kelas eksperimen dan kelas kontrol pada siswa dengan motivasi belajar tinggi dapat dilihat pada Tabel 5.6.

Tabel 5.6 Hasil Analisis Perbedaan Kemampuan Berpikir Kritis antara Model Tri Pramana SPA dengan Model Konvensional pada Siswa Dengan Motivasi Belajar Tinggi

\begin{tabular}{|c|c|c|c|c|c|}
\hline \multicolumn{6}{|c|}{ ANAVA } \\
\hline CTTinggi & & & & & \\
\hline & Sum of Squares & $\mathrm{df}$ & Mean Square & $\mathrm{F}$ & Sig. \\
\hline Between Groups & 837.402 & 1 & 837.402 & 26.463 & .000 \\
\hline Within Groups & 822.754 & 26 & 31.644 & & \\
\hline Total & 1660.156 & 27 & & & \\
\hline
\end{tabular}

Data Tabel 5.6 menunjukkan bahwa nilai $\mathrm{p}=0,000<\alpha=0,05$, sehingga maka Ho ditolak dan $\mathrm{H} 1$ diterima. Dengan demikian maka dapat disimpulkan bahwa terdapat perbedaan kemampuan berpikir kritis yang signifikan antara Model Tri Pramana SPA dengan Model Pembelajaran Konvensional pada siswa yang motivasi belajarnya tinggi. Model Tri Pramana SPA lebih unggul pada siswa yang motivasinya tinggi dikarenakan karakteristiknya yang mampu mengakomodasi dan memfasilitasi siswa dengan motivasi belajar yang tinggi. Misalnya ketika fase Pratyaksa yaitu ketika siswa melakukan praktikum, siswa dilibatkan dalam kegiatan investigasi bermakna sebagai salah satu jalan untuk melakukan verifikasi atas pengetahuan deduktifnya.Utama dkk. (2013) menyatakan bahwa siswa akan dapat memanipulasi bahan ataupun benda praktikum secara nyata dengan menggunakan seluruh panca inderanya.

Model Tri Pramana SPA dapat menumbuhkan minat serta motivasi belajar siswa, khususnya pada siswa dengan motivasi belajar yang tinggi. Siswa dengan motivasi yang tinggi memiliki tujuan belajar yang jelas yaitu untuk menjadi yang terbaik selama proses pembelajaran. Disamping itu karakteristik siswa dengan motivasi belajar yang tinggi adalah sangat menyenangi tantangan baru (pursuit of challenge) di dalam pembelajaran. Rasa ketertarikan siswa dengan motivasi tinggi akan dipenuhi dengan melakukan proses eksperiment di laboratorium setelah mendapatkan teorinya secara deduktif. Untuk memperkuat memori tersebut dalam fase Anumana Pramana akan penjelasan materi tersebut di dalam konteks yang berbeda, yaitu implikasinya dalam 
kehidupan sehari-hari. Hal ini akan membantu proses transformasi pengetahuan siswa, khususnya keterampilan berpikir kritis siswa baik melalui proses asimilasi maupun proses akomodasi pengetahuan.

\section{Perbedaan Kemampuan Berpikir Kritis antara Model Tri Pramana SPA dengan Model Pembelajaran Konvensional pada Siswa Dengan Motivasi Belajar Rendah.}

Adapun hasil analisis ANAVA Satu Jalur jalur perbedaan kemampuan berpikir kritis siswa antara kelas eksperimen dan kelas kontrol pada siswa dengan motivasi belajar rendah dapat dilihat pada Tabel 5.7 .

Tabel 5.7 Hasil Analisis Perbedaan Kemampuan Berpikir Kritis antara Model Tri Pramana SPA dengan Model Konvensional pada Siswa Dengan Motivasi Belajar Rendah

\begin{tabular}{|c|c|c|c|c|c|c|}
\hline \multicolumn{7}{|c|}{ ANAVA } \\
\hline & & & & & & \\
\hline & Sum of Squares & $\mathrm{df}$ & Mean Square & $\mathrm{F}$ & Sig. & \\
\hline Between Groups & 1255.580 & 1 & 1255.580 & 23.847 & & .000 \\
\hline Within Groups & 1368.931 & 26 & 52.651 & & & \\
\hline Total & 2624.512 & 27 & & & & \\
\hline
\end{tabular}

Data Tabel 5.6 menunjukkan bahwa nilai $\mathrm{p}=0,000<\alpha=0,05$, sehingga maka Ho ditolak dan $\mathrm{H} 1$ diterima. Dengan demikian maka dapat disimpulkan bahwa terdapat perbedaan kemampuan berpikir kritis yang signifikan antara Model Tri Pramana SPA dengan Model Pembelajaran Konvensional pada siswa yang motivasi belajarnya rendah. Siswa yang memiliki motivasi belajar rendah memiliki kecenderungan menyimpang yang tinggi dan memiliki konsentrasi belajara yang kurang dalam proses pembelajaran. Namun bukan berarti siswa tersebut tidak memiliki potensi belajar yang baik. Potensi belajar siswa dengan motivasi belajar yang rendah akan terabaikan jika guru tidak memberikan kesempatan belajar yang sama kepada siswa tersebut.Siswa yang memiliki motivasi belajar rendah merupakan siswa yang sulit secara konsisten menentukan tujuan belajarnya dan berkonsentrasi di dalam pembelajaran. Umumnya siswa yang tergolong dalam kategori ini merupakan siswa yang secara akademik memiliki prestasi belajar yang kurang. Dalam Model Tri Pramana SPA, siswa dilibatkan dan diberikan kesempatan yang sama di dalam kegiatan yang bermakna. Dengan memiliki kesempatan belajar yang sama, siswa dengan motivasi belajar yang rendah akan mampu mengembangkan potensi terbaiknya di dalam pembelajaran.

Dalam pemecahan masalahnya Model Tri Pramana SPA memberikan siswa kesempatan menyelesaikan soal dengan cara termudah yang dipahaminya. Cara ini juga akan memberikan keleluasaan siswa di dalam pembelajaran dan akan mampu mengembangkan kemampuan berpikir kritis siswa. Subagia \& Wiratma (2007) juga menyatakan bahwa Model Tri PramanaSPA adalah 
konsep belajar yang menekankan pada kemajemukan cara yang ditempuh dalam membangun pengetahuan.

\section{Pengaruh Interaktif Antara Model} Pembelajaran Dan Motivasi Belajar Terhadap Kemampuan Berpikir Kritis Siswa

Hasil analisis interaksi antara model pembelajaran dan motivasi belajar terhadap kemampuan berpikir kritis siswa dalam penelitian ini dianalisis dengan menggunakan ANAVA Dua Jalur. Adapun hasil analisisnya dapat dilihat pada Tabel 5.8.

Tabel 5.8 Hasil Analisis ANAVA Dua Jalur Interaktif Antara Model Pembelajaran Dan Motivasi Belajar Terhadap Kemampuan Berpikir Kritis Siswa

\begin{tabular}{lrrrrr}
\hline \multicolumn{6}{c}{ Tests of Between-Subjects Effects } \\
\hline Dependent Variable:CTWithMo & \multicolumn{1}{c}{} & & \\
\hline & Type III Sum of & & & & \\
Source & Squares & df & Mean Square & \multicolumn{1}{c}{ F } & Sig. \\
\hline Corrected Model & $2169.887^{\mathrm{a}}$ & 3 & 723.296 & 17.161 & .000 \\
Intercept & 18875.732 & 1 & 18875.732 & 447.846 & .000 \\
Motivasi & 76.904 & 1 & 76.904 & 1.825 & .183 \\
Jenis_Model & 2071.882 & 1 & 2071.882 & 49.158 & .000 \\
Motivasi $*$ Jenis_Model & 21.101 & 1 & 21.101 & .501 & .482 \\
Error & 2191.685 & 52 & 42.148 & & \\
Total & 23237.305 & 56 & & & \\
Corrected Total & 4361.572 & 55 & & & \\
a. R Squared $=.498$ (Adjusted R Squared $=.469)$ & & & & \\
\hline
\end{tabular}

Data Tabel 5.8 menunjukkan bahwa nilai $\mathrm{p}=0,482>\alpha=0,05$, sehingga maka Ho diterima dan H1 ditolak. Dengan demikian maka dapat disimpulkan bahwa tidak terdapat pengaruh interaksi antara model pembelajaran dengan motivasi belajar siswa terhadap kemampuan berpikir kritis siswa di SMP Negeri 7 Denpasar. Kedua jenis variabel yaitu motivasi belajar dan model pembelajaran tidak memberikan pengaruh secara simultan terhadap kemampuan berpikir kritis siswa. Gambar 5.1 berikut menunjukkan pengaruh interaksi antara model pembelajaran dengan motivasi belajar.

Gambar 5.1 Interaksi antara Model Pembelajaran dengan Motivasi Belajar Terhadap Kemampuan Berpikir Kritis Siswa.

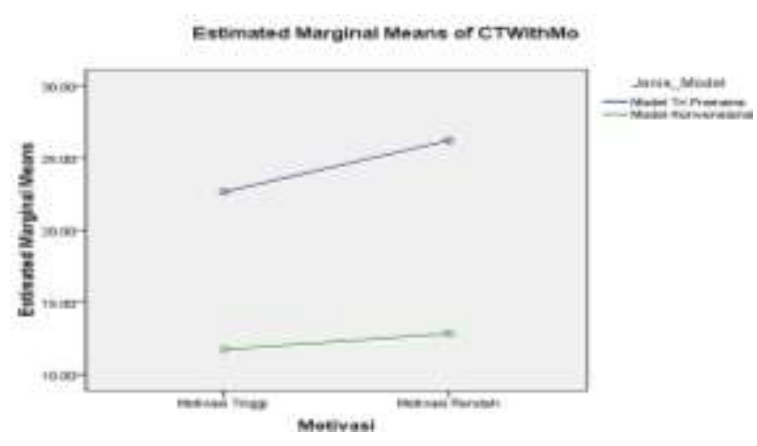

Walaupun belum terdapat interaksi antara model pembelajaran dengan motivasi belajar, namun melihat kemiringan dari grafik interaksi tersebut dapat disimpulkan apabila jumlah sampel dalam penelitian ditambah. Sehingga dapat dibayangkan apabila ditarik suatu garis imajiner pada masing-masing variabel, akan terjadi perpotongan garis yang menunjukkan interaksi menyeluruh antara model pembelajaran dengan motivasi belajar. 


\section{PENUTUP}

\section{Kesimpulan}

Adapun kesimpulan yang diperoleh dalam penelitian ini adalah sebagai berikut:

1) Terdapat perbedaan yang signifikan antara Model Tri Pramana SPA dengan Model Konvensional $(\mathrm{p}=0,000<\alpha=$ $0,05)$.

2) Terdapat perbedaan kemampuan berpikir kritis yang signifikan antara Model Tri Pramana SPA dengan Model Pembelajaran Konvensional pada siswa yang motivasi belajarnya tinggi $(p=0,000<\alpha=0,05)$.

3) Terdapat perbedaan kemampuan berpikir kritis yang signifikan antara Model Tri Pramana SPA dengan Model Pembelajaran Konvensional pada siswa yang motivasi belajarnya rendah $(p=0,000<\alpha=0,05)$.

4) Tidak terdapat pengaruh interaksi antara model pembelajaran dengan motivasi belajar siswa terhadap kemampuan berpikir kritis siswa $(\mathrm{p}=0,482>\alpha=0,05)$

\section{Saran}

Adapun saran dari penelitian ini adalah sebagai berikut:
1) Menarik untuk dikaji variasi dari Model Siklus Belajar Tri Pramana selain Tipe SPA yaitu Tipe APS(Anumana, Pratyaksa, dan Sabda) dan PSA (Pratyaksa, Sabda dan Anumana) dalam sebuah penelitian komparatif yang terkait dengan kemampuan berpikir kritis siswa.

2) Menarik untuk dikaji secara lebih lanjut variabel variabel moderator lain yang kemungkinan memiliki pengaruh interaksi dengan Model Siklus Belajar Tri Pramana dalam kaitannya dengan kemampuan berpikir kritis siswa yaitu Gaya Kognitif, Gaya Belajar dan Gender.

3) Masih sedikit terdapat penelitian komparatif yang membandingkan antara Model Siklus Belajar Tri Pramana ini dengan Model Siklus Belajar lainnya. Sehingga penelitian selanjutnya akan memberikan gambaran keunggulan dan kelemahan Model Siklus Belajar Tri Pramana dibandingkan dengan Model Siklus Belajar yang lain.

\section{DAFTAR PUSTAKA}

$$
\begin{array}{rr}
\text { Arnyana.(2004). } & \text { Pengembangan } \\
\text { Perangkat } & \text { Model }
\end{array}
$$


Berdasarkan Masalah Dipandu Strategi Kooperatif Serta Pengaruh Implementasinya Terhadap Kemampuan Berpikir Kritis dan Hasil Belajar Siswa Sekolah Menengah Atas Pada Pelajaran Ekosistem.Disertasi(tidak diterbitkan).Malang: Universitas Negeri Malang.

Bandura, A. (2001). "Social cognitive theory: An agentive perspective". Annual Review of Psychology, Volume 52, Nomor 1 (hlm. 1-26).

Darma, K. (2007). Pengaruh model pembelajaran konstruktivisme terhadap prestasi belajar matematika terapan pada mahasiswa Politeknik Negeri Bali. Jurnal Pendidikan dan Kebudayaan Nomor.70.

Ennis, R.H.(1985). A Logical Basis for Measuring Critical Thinking Skills. Educational Leadership. Nomor 43, Volume 2.

Glynn, S. M., G. Taasoobshirazi, P. Brickman. (2009). Nonscience majors learning science: A theoretical model of motivation.Journal of Research In Science Teaching, Volume 46, Nomor 2 (hlm. 127-146).

Glynn, S.M., \& Koballa, T.R.,Jr.(2006). Motivation to learn college science. In Joel J. Mintzes and William H. Leonard (Eds.). Handbook of College Science Teaching (pp.2532).Arlington, VA: National Science Teacher Assosiation Press.

Johnson, E. B.(2002).Contextual Teaching and Learning.California: Corwin Press, Inc.

Liliasari.(2000). Model Pembelajaran untuk Meningkatkan Keterampilan Konseptual Tingkat Tinggi Calon Guru IPA. Prosiding Seminar Nasional.Dirjen Dikti DepdiknasJICA-IMSTEP.Malang:

Februari.

OECD.(2013).PISA 2012 results: whats student know and can do-student performance in mathematics, reading and science (volume $i$ ).[Online]. Tersedia pada :http://www.oecd.org. (diakses pada tanggal 01 Juli 2015).

Sadewo, J.(2015). Kemana Arah Pendidikan Indonesia?.[Online]. Tersedia pada: http://www.republika.co.id/berita/ pendidikan/eduaction/14/02/27/n1n ns0-kemana- arah pendidikanindonesia (diakses pada tanggal 01 April 2016).

Santyasa, I W. (2004). Pengaruh model dan seting pembelajaran terhadap remediasi miskonsepsi, pemahaman konsep, dan hasil belajar siswa pada siswa SMU. Disertasi (tidak diterbitkan). Universitas Negeri Malang.

Santrock, J. W. (2008). Psikologi pendidikan, Edisi Kedua. Jakarta: Kencana.

Shadiq, F. (2004). Implikasi konstruktivismedalam

pembelajaran matematika sekolah dasar. Tersedia pada http://fadjarp3g.files.wordpress.co $\mathrm{m} / 2007 / 09$

Imed2konstruksdok_median_pdf. Diakses tanggal 5 April 2017.

Sigler, E. A. \& Saam, J. (2007).Constructivist or expository instructional approach: Does instruction have an effect on the accuracy of Judgement of Learning (JOL). Journal of the Scholarship of Teaching and Learning, Volume 7 Nomor 2(hlm. 22-31).

Suastra, I Wayan. (2006). Belajar dan Pembelajaran. Singaraja : IKIP Negeri Singajara.

Subagia, I.W. \& Lanang W. I.G.(2005). Pengembangan Model Siklus Belajar Berdasarkan PotensiPotensi Kearifan Lokal Masyarakat Bali Dalam Bidang Pendidikan. Laporan Penelitian Hibah Bersaing. Singaraja : IKIP Singaraja. 
Subagia, I W. dan Wiratma, I G. L. 2007.

Model Siklus Belajar Berbasis

Kearifan Lokal Masyarakat Bali.

Singaraja: Universitas Pendidikan

Ganesha.

Suma, K. (2005). Efektivitas kegiatan laboratorium konstruktivis dalam meningkatkan penguasaan konsepkonsep arus searah mahasiswa calon guru. Jurnal Pendidikan dan Pengajaran IKIP Negeri Singaraja. 38(2), 159 - 171.

Utama, A. A. P. A. A. S., Agung, Riastin.(2013).Pengaruh Siklus Belajar Berbasis Tri Pramana Terhadap Keterampilan Berpikir Kritis IPA Siswa Kelas V SD Di Gugus V Kecamatan Sawan. Jurnal Portal Garuda. Diunduh dari 
